\title{
Preliminary Estimates of Biological and Yield Characteristics of Deep-water Witch Flounder (Glyptocephalus cynoglossus) in the Georges Bank - Mid-Atlantic Bight Region
}

\author{
S. E. Wigley and J. M. Burnett \\ Northeast Fisheries Science Center, 166 Water Street \\ Woods Hole, MA 02543, USA
}

\begin{abstract}
The existence of a deep-water (greater than $366 \mathrm{~m}$ ) resource of witch flounder (Glyptocephalus cynoglossus) along the northeastern U.S continental slope and adjacent abyssal plain is suggested by several lines of evidence including: 1) egg and larval distribution patterns; 2) by-catch rates in deep-water surveys for red crab (Chaceon quinquedens) and monkfish (Lophius americanus); and 3) various special deep-water studies conducted as far south as Virginia. Nothing is known regarding the abundance, biology, and production rates of these fish, nor their affiliation to witch flounder in shallower shelf waters. Recent opportunistic sampling at depths ranging between 367$914 \mathrm{~m}$ has provided a limited number of samples for the preliminary estimation of growth and maturation rates. When compared to witch flounder of the shallower regions of the Gulf of Maine and Georges Bank, growth rates for deep-water fish are considerably lower and maturation occurs at an older age.
\end{abstract}

Production rates (yield-per-recruit) are calculated for deep-water witch flounder and compared with those for the exploited Gulf of Maine resource (NAFO Div. 5Y). Implications for the management of a potential future fishery for currently unexploited deep-water witch flounder are discussed.

Keywords: deep-water, growth, maturity, witch flounder, yield

\section{Introduction}

Witch flounder, Glyptocephalus cynoglossus, is distributed on both sides of the North Atlantic. In the Northwest Atlantic, they range from Labrador southward to Virginia, and are closely associated with mud or sand-mud bottom at a variety of depths, especially between $110-275 \mathrm{~m}$ but rarely less than 30 $\mathrm{m}$. No seasonal movements or migrations are reported for this species in the Northwest Atlantic, and witch flounder appear to be rather sedentary (Bigelow and Schroeder, 1953; Klein-MacPhee, 2002).

Witch flounder are commercially abundant off the northeastern coast of the United States, and support an important fishery in the Gulf of Maine region (NAFO Div. 5Y; Wigley et al., MS 1999). This stock is well-studied, including studies of ecology and distribution (Bigelow and Schroeder, 1953; Burnett et al., 1992), length-weight relationships (Lux, 1969), age and growth (Burnett et al., 1992), reproductive biology (Burnett et al., 1992; O'Brien et al., 1993), feeding ecology (Bowman and Michaels, 1984), egg and larval distributions (Berrien and Sibunka, 1999 and Smith et al., 1975, respectively), and fishery yield characteristics (Burnett, MS 1987; Wigley, MS 1994; Wigley et al., MS 1999).

The existence of a deep-water population of witch flounder in continental slope waters south of Georges Bank and southern New England (NAFO Div. 5Z and Subarea 6; Fig. 1) has long been known but remains poorly studied, and the relationship of this population to that of the Gulf of Maine is not understood. Goode and Bean (1895) first reported the occurrence of these deep-water witch flounder, and Bigelow and Schroeder (1953) found them down to depths of $1565 \mathrm{~m}$. Markle and Musick (1974) noted that juvenile witch flounder were a dominant species along a continental slope transect off Virginia at $900 \mathrm{~m}$ depth. Markle (1975) found witch flounder, mostly juveniles, at every station between 256 and $1080 \mathrm{~m}$ and as deep as $1408 \mathrm{~m}$ during deep-water sampling at Norfolk Canyon (Fig. 1). During a Northeast Fisheries Science Center 


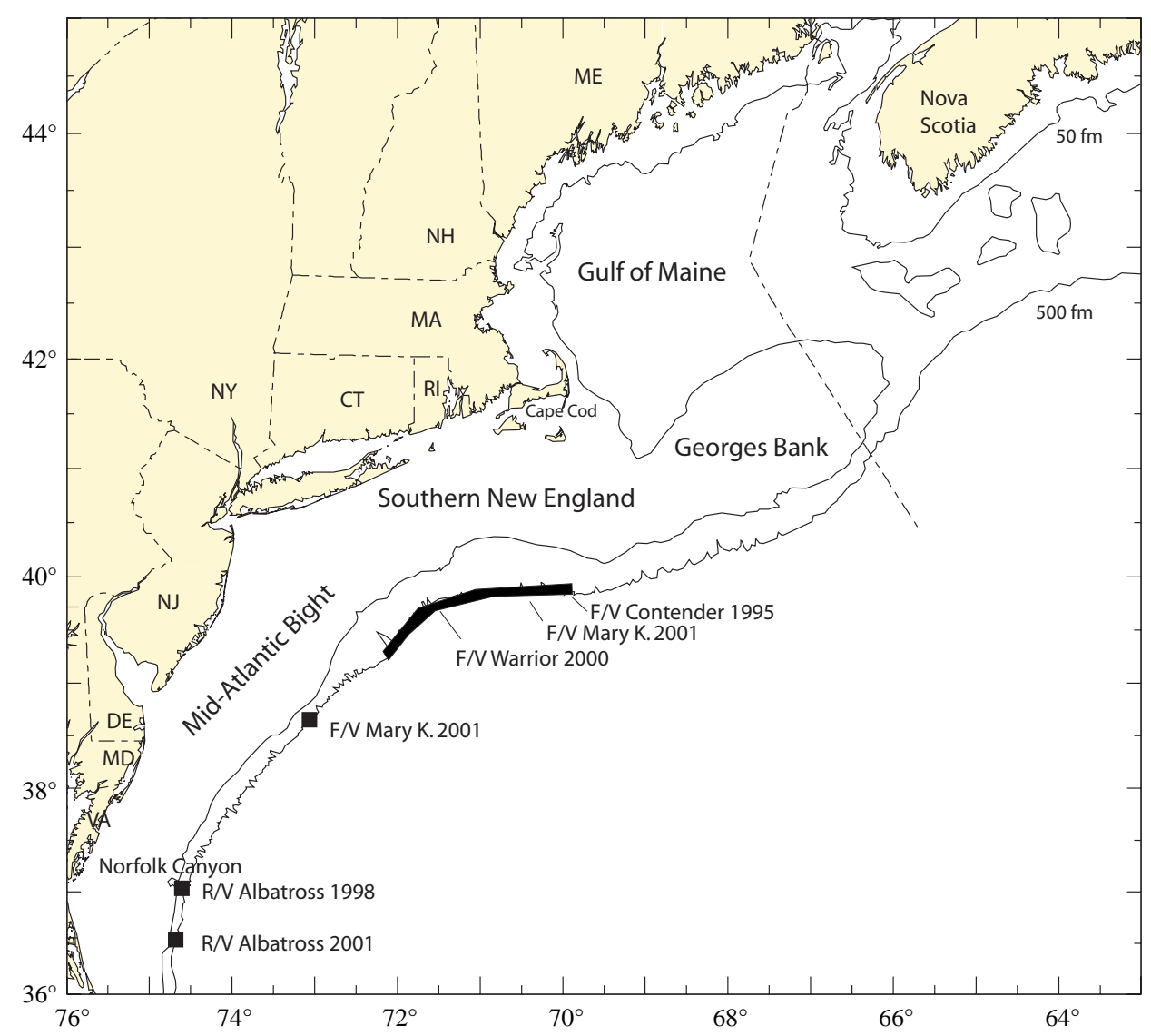

Fig. 1. Continental shelf and slope areas along the northeast coast of the United States, with deep-water sampling areas indicated in solid polygons.

(NEFSC) 1980 survey for red crab, Chaceon quinquedens, in southern New England slope waters, witch flounder of $6-35 \mathrm{~cm}$ total length were caught in about half the trawl tows conducted at depths between 273 and $1371 \mathrm{~m}$ (unpublished NEFSC data, Appendix Table 1).

Whether these deep-water witch flounder constitute a separate group from the Gulf of Maine fish has not been resolved. Bigelow and Schroeder (1953) observed no spawning of witch flounder west of Cape Cod. Markle (1975), while reporting a few adult-sized fish and some recently metamorphosed postlarvae in the vicinity of Norfolk Canyon, attributed the presence of deep-water juveniles to passive transport via shelf circulation of long-lived larvae from northern spawning contingents, and hypothesized that the deep-water witch flounder represented "stunted expatriates" from the Gulf of Maine stock. However, temporal distribution patterns of eggs (most recently Berrien and Sibunka, 1999) and larvae (Smith et al., 1975), coupled with NEFSC survey samples of reproductively active fish from deep-water areas, led Burnett (MS 1987) to conclude that spawning occurs among deep-water witch flounder in Mid-Atlantic Bight slope waters, thus a separate population exists.

Deep-water biological samples of witch flounder from the slope waters south of Georges Bank and MidAtlantic Bight are analyzed in this study. Markle (1975) observed that "an analysis of age and growth of Virginian witch flounder... would be interesting." Thus, the objectives of this study were to: a) describe biological characteristics, including growth and maturation rates and length-weight relationships of deep-water witch flounder; b) compare these attributes with those of the Gulf of Maine and Mid-Atlantic Bight shelf regions; and c) provide preliminary estimates of production rates. 


\section{Methods}

Witch flounder samples were collected during NEFSC winter, spring and autumn research vessel bottom trawl surveys (see Azarovitz, 1981 for a description of the NEFSC survey program, design, and methodology) and during two series of special surveys conducted to collect information on deep-water fishes and monkfish (Lophius americanus), respectively (Table 1). For witch flounder collected during NEFSC surveys, the following information was obtained at sea: total length $(\mathrm{cm})$, total weight $(\mathrm{g})$, and gender and maturity stage. Gender and maturity stage were determined from macroscopic examination of the gonads and classified into the following categories: unsexed, females, or males, and immature, developing, ripe, ripe and running, spent or resting, respectively, based upon criteria described by Burnett et al. (1989). Both sagittal otoliths were removed for age determinations. Witch flounder collected during the deep-water surveys were frozen whole at sea and processed as above back at the laboratory after thawing.

Analyses were performed for three geographic regions: 1) the Gulf of Maine and northern Georges Bank region; 2) the Mid-Atlantic Bight shelf region encompassing the continental shelf area from southern Georges Bank to Virginia at depths less than $367 \mathrm{~m}$; and 3) deep-water (>366 m) slope waters. Data used for regions 1 and 2 above were from 1994-99 NEFSC surveys, encompassing a period of stable growth and maturity rates (Wigley et al., MS 1999), while data for region 3 were collected during 1995-2001. Due to the low number of fish in regions 2 and 3 (137 and
271 fish, respectively) analyses of growth and lengthweight relationships were conducted with genders combined for all regions. Data for witch flounder in the deep-water region were further analyzed to evaluate possible trends in growth with increasing depth. Data were partitioned into two depth zones, $367-500 \mathrm{~m}$ and greater than $500 \mathrm{~m}$.

Otoliths were thin-sectioned according to the methodology described by Penttila et al. (1988) and aged as described by Burnett (1988). Growth was modeled by fitting the following semi-logarithmic function:

$$
\text { length }=a+b \ln (\text { age })
$$

to length-at-age data (Bowers, 1960; Roff, 1980), and regression equations compared between regions and depth zones using tests for heterogeneity of slopes (Sokal and Rohlf, 1995). Length-weight relationships were described by the following regression:

$$
\ln (\text { weight })=a+b \ln (\text { length }),
$$

and compared as above. Maturity data were analyzed for each region by gender and, for the deep-water region, by depth zone, to estimate proportions mature at length and age using probit analysis (Finney, 1971); analyses were based upon data for sampled fish only and not expanded by catch to the population level as suggested by Morgan and Hoenig (1997) due to the use of multiple vessels and gears and unequal tow durations during the opportunistic sampling. Growth, length-weight, and maturity analyses were performed using SAS procedures GLM and PROBIT, respectively (SAS, 1985).

TABLE 1. Summary of opportunistic surveys from which deep-water witch flounder were obtained for this study. Location

\begin{tabular}{|c|c|c|c|c|c|}
\hline Vessel & Date & Location & $\begin{array}{c}\text { Depth Range } \\
(\mathrm{m})\end{array}$ & $\begin{array}{c}\text { Number of } \\
\text { stations }\end{array}$ & $\begin{array}{l}\text { Number of } \\
\text { fish }\end{array}$ \\
\hline F/V Contender & October, 1995 & $39^{\circ} 52^{\prime} \mathrm{N}, 69^{\circ} 58^{\prime} \mathrm{W}$ & 452 & 1 & 18 \\
\hline R/V Albatross IV & March, 1998 & $36^{\circ} 58^{\prime} \mathrm{N}, 74^{\circ} 36^{\prime} \mathrm{W}$ & 560 & 1 & 2 \\
\hline F/V Warrior & October, 2000 & $\begin{array}{l}39^{\circ} 18^{\prime} 22^{\prime \prime}-39^{\circ} 58^{\prime} 29^{\prime \prime} \mathrm{N} \\
69^{\circ} 53^{\prime} 30^{\prime \prime}-72^{\circ} 14^{\prime} 45^{\prime \prime} \mathrm{W}\end{array}$ & $357-618$ & 14 & 199 \\
\hline $\mathrm{R} / \mathrm{V}$ Albatross IV & February, 2001 & $36^{\circ} 35^{\prime} 89^{\prime \prime} \mathrm{N}, 74^{\circ} 42^{\prime} 42^{\prime \prime} \mathrm{W}$ & 387 & 1 & 4 \\
\hline F/V Mary K & March, 2001 & $38^{\circ} 40^{\prime} 76^{\prime \prime} \mathrm{N}, 73^{\circ} 04^{\prime} 32^{\prime \prime} \mathrm{W}$ & 397 & 1 & 5 \\
\hline F/V Mary $K$ & April, 2001 & $\begin{array}{l}39^{\circ} 51^{\prime} 17^{\prime \prime}-39^{\circ} 53^{\prime} 61^{\prime \prime N} \\
69^{\circ} 42^{\prime} 18^{\prime \prime}-70^{\circ} 36^{\prime} 51^{\prime \prime} \mathrm{W}\end{array}$ & $433-914$ & 5 & 43 \\
\hline
\end{tabular}
indicates polygons of degrees and minutes of latitude and longitude. 
TABLE 2. Results of witch flounder growth modeling, including sample sizes, regression coefficients and associated statistics, by region.

\begin{tabular}{lrrrrrr}
\hline \hline Region & $\mathrm{N}$ & Intercept & $(\mathrm{SE})$ & Slope & $(\mathrm{SE})$ & $r^{2}$ \\
\hline Gulf of Maine & 1953 & 4.5960 & $(0.1817)$ & 17.2675 & $(0.1205)$ & 0.9133 \\
Mid-Atlantic Bight shelf & 127 & 2.1864 & $(0.9000)$ & 17.8559 & $(0.5448)$ & 0.8950 \\
Deep-water & & & & & & \\
$\quad$ All Depths & 271 & -8.4173 & $(1.9147)$ & 20.2867 & $(0.9204)$ & 0.6436 \\
367-500 m & 173 & -5.9345 & $(2.5713)$ & 19.1770 & $(1.2456)$ & 0.5809 \\
$>500 \mathrm{~m}$ & 98 & -11.5745 & $(2.9317)$ & 21.6246 & $(1.3904)$ & 0.7159 \\
\hline
\end{tabular}

Estimates of yield-per-recruit and spawning stock biomass-per-recruit were generated for deep-water witch flounder using the method of Thompson and Bell (1934), and compared to those derived for the Gulf of Maine stock by Wigley et al. (MS 1999). The deep-water exploitation pattern was based on mesh selectivity of a 6 inch mesh $(152 \mathrm{~mm}$, the regulated mesh for groundfish in the USA Northeast region since 1994); selection at age was determined by aligning the selection at length pattern of the Gulf of Maine stock with deep-water mean lengths at age. Natural mortality was assumed to be 0.15 , following the practice of Burnett (MS 1987) and Wigley et al. (MS 1999). While no fishery currently exists for the deepwater group, the proportion of fishing and natural mortality occurring before spawning was assumed to be 0.167 , reflecting late winter-early spring spawning (Berrien and Sibunka, 1999) and an anticipated corresponding fishery on pre-spawning aggregations (Burnett et al., 1992).

\section{Results}

Lengths for the 271 deep-water witch flounder ranged from 21 to $52 \mathrm{~cm}$, and ages ranged from 4 to 16 years (Fig. 2A and 2B, respectively). There were 172 females and 99 males, with the largest male being $44 \mathrm{~cm}$ and the oldest male being age 11. The microstructure of otoliths from deep-water witch flounder revealed many more splits and checks than seen in otoliths from Gulf of Maine fish, probably the result of the very different temperature regimes between regions. Even more unusual was the overall shape of otoliths from most (66\%) deep-water witch flounder, particularly the right (top) otolith, which had a pronounced domed shape compared to Gulf of Maine otoliths (Fig. 3).
Analysis of growth resulted in highly significant $(p<0.001)$ relationships between length and age for all three regions (Table 2). While growth was similar for witch flounder from the Gulf of Maine and MidAtlantic Bight shelf regions, deep-water witch flounder grew more slowly $(p<0.001$, heterogeneity of slopes, $\mathrm{df}=2$; Fig. 4). Among the deep-water fish, there was no evidence of decreased growth with increasing depth ( $p=0.2121$, heterogeneity of slopes, df $=1$; Table 2).

Differences in the length-weight relationship were also noted among the three regions $(p<0.001$, heterogeneity of slopes, $\mathrm{df}=2$ ). The exponent for deep-water witch flounder (3.8) is considerably greater than that of other regions in this study (Table 3 ), and results in divergence of predicted weight at age compared to Gulf of Maine and Mid-Atlantic Bight shelf region fish beyond $40 \mathrm{~cm}$ (Fig. 5). This exponent is greater than any previously published value for witch flounder across the species' entire range (Powles, 1967; Lux, 1969; Kohler et al., MS 1970; Bowering and Stansbury, 1984; Steinarsson et al., MS 1989; Nilsen et al., 1991).

Although the majority of maturity observations for deep-water witch flounder were of immature fish, several mature fish were encountered (Table 4). The gonads of deep-water witch flounder appeared similar in size and shape from those of the other two regions. One observation was omitted for a $26 \mathrm{~cm}$ female due to the poor condition of the gonad following freezing and thawing. The probit model did not provide acceptable fits (Chi-square goodness of fit, $p>0.05$ ) to maturity data for Mid-Atlantic Bight shelf region witch flounder, and these analyses are not presented. Median size and age at maturity were significantly 

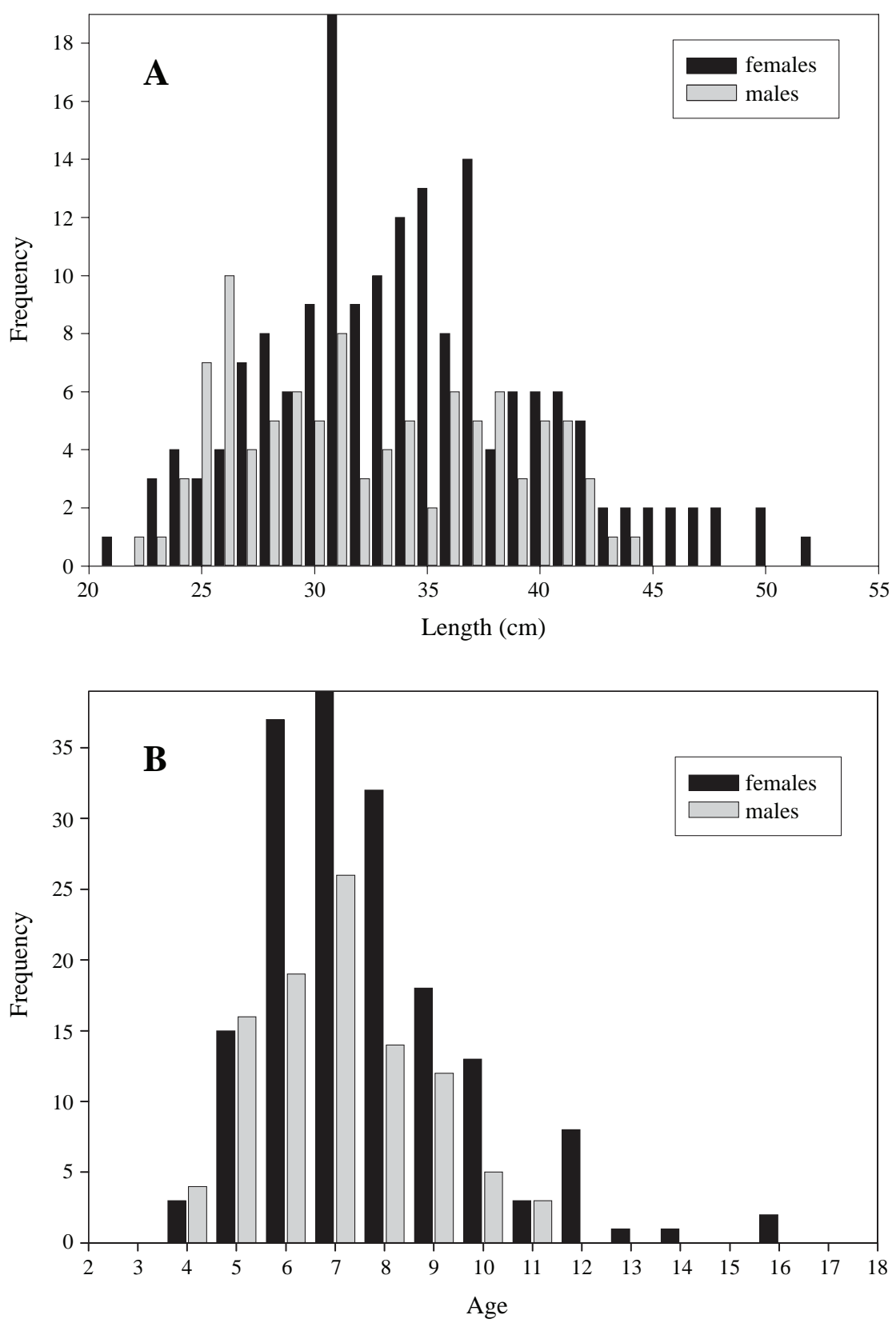

Fig. 2. Length (A) and age (B) distributions by gender for 271 deep-water witch flounder collected during 1995-2001 in slope waters of the Georges BankMid-Atlantic region.

different for both male and female witch flounder from deep-water compared to the Gulf of Maine (Table 5), with deep-water fish maturing at a slightly larger size but a much greater age. For example, the median size at maturity for females differed by only $2.2 \mathrm{~cm}$, but the median age differed by 3.7 years (Fig. 6), further illustrating the much slower growth rate of deep-water witch flounder. Estimates of median length at maturity were not significantly different $(p>0.05)$ between depth zones for either gender (Table 5). Median age of maturity was not estimated due to poor fit of the probit model to maturity at age data by depth zones. 


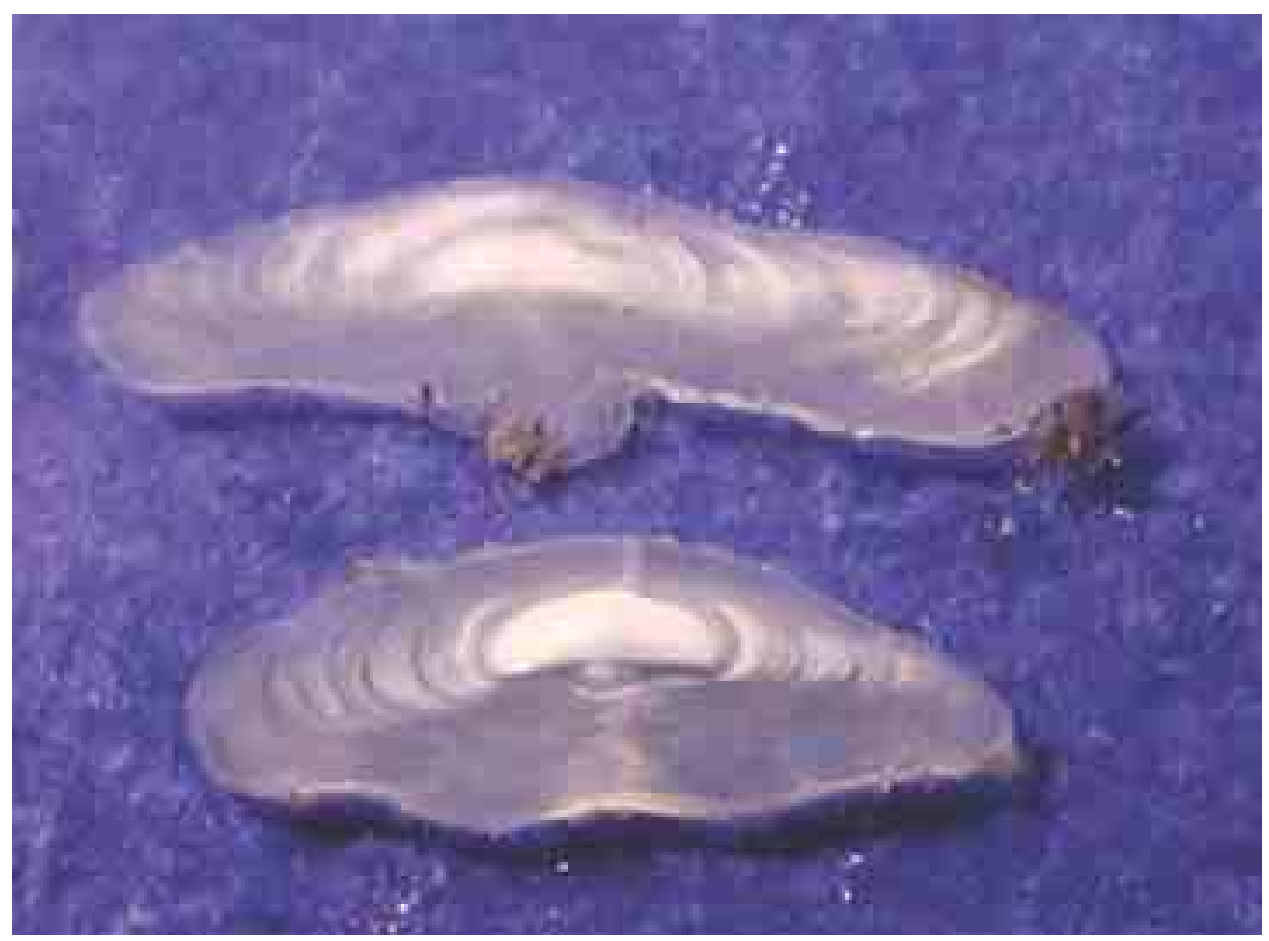

Fig. 3. Comparison of otolith thin-sections illustrating differences in overall shape between a 45 $\mathrm{cm}$ female witch flounder collected in the Gulf of Maine during the NEFSC 1999 autumn bottom trawl survey (top) and a $28 \mathrm{~cm}$ female witch flounder caught during a spring 2001 deep water survey aboard the F/V Mary K (bottom). Both fish were determined to be age 10. The dome shape of the otolith from the deep-water specimen was characteristic of witch flounder collected in deep water, occurring in $66 \%$ of the total sample.

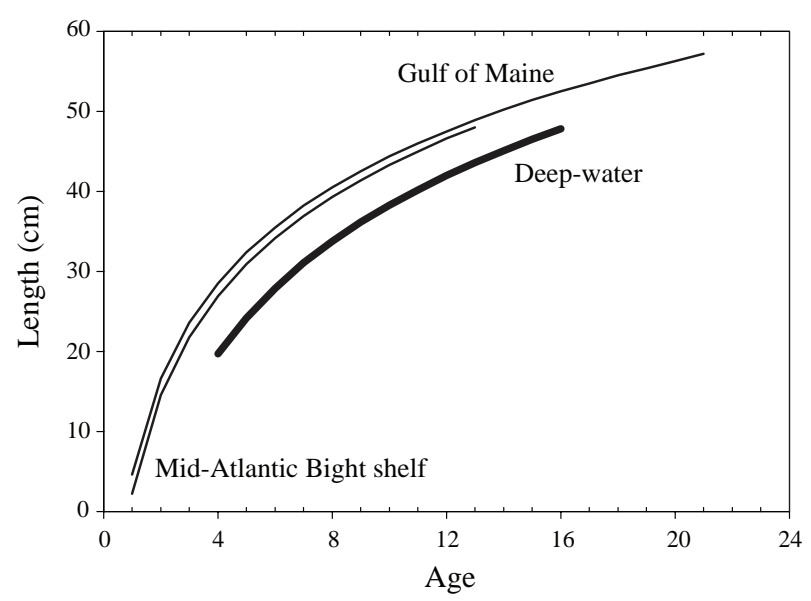

Fig. 4. Growth curve comparisons of Gulf of Maine, MidAtlantic Bight shelf and deep-water witch flounder. End points of curves correspond to minimum and maximum ages observed in each region.

Estimates of yield-per-recruit from deep-water witch flounder were considerably lower than those for the Gulf of Maine, and the flat-top shape of the yield curve was in sharp contrast to the dome-shape curve for the Gulf of Maine. Maximum yield-per-recruit for deep-water witch flounder was only $48 \%$ of the value for the Gulf of Maine and occurred at a higher level of fishing mortality $(F=0.52$ vs. 0.30 ; Fig. 7, Appendix Table 2), reflecting the delayed entry at age of deep-water witch flounder to the potential fishery due to slower growth. Estimates of spawning stock biomass-per-recruit for deep-water fish were only about one-half of those for Gulf of Maine witch flounder at low levels of fishing (Fig. 7, Appendix Table 2), reflecting the combination of slower growth and delayed maturation.

\section{Discussion}

Several lines of evidence would seem to de-couple deep-water witch flounder from the population of witch flounder in the Gulf of Maine-northern Georges Bank region, and thus refute Markle's (1975) hypothesis that deep-water witch flounder south of 
TABLE 3. Results of witch flounder length-weight modeling including sample sizes, regression coefficients and associated statistics, by region.

\begin{tabular}{|c|c|c|c|c|}
\hline Region & $\mathrm{N}$ & Intercept (SE) & Slope (SE) & $r^{2}$ \\
\hline Gulf of Maine & 1945 & -12.8990 & $(0.0074)$ & 0.9898 \\
\hline Mid-Atlantic Bight shelf & 133 & -13.3698 & $(0.0374)$ & 0.9841 \\
\hline Deep-water & 271 & -14.9197 & $(0.0432)$ & 0.9665 \\
\hline
\end{tabular}

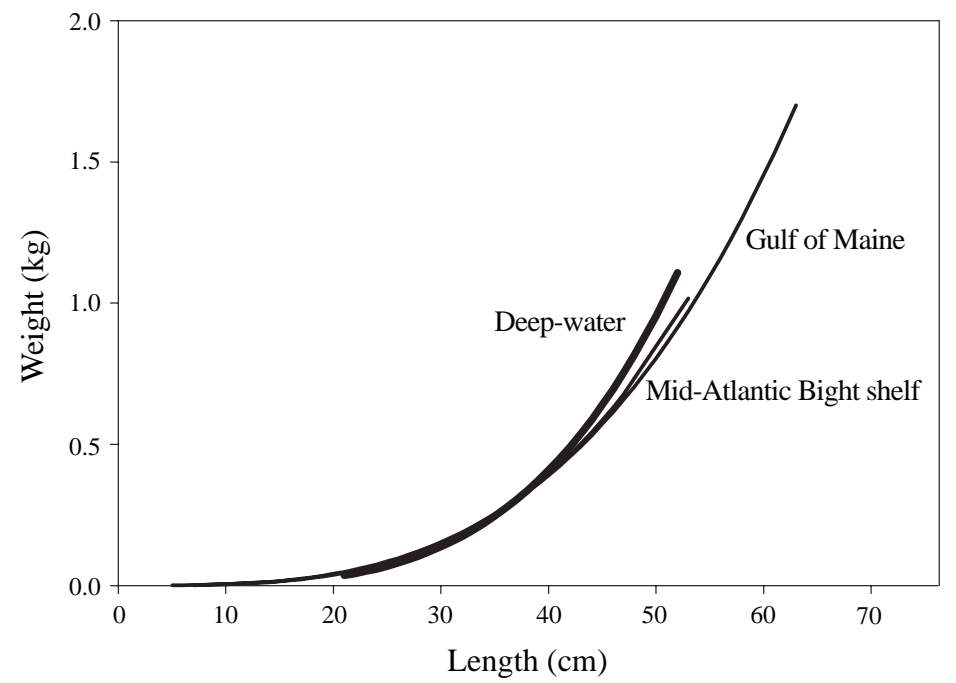

Fig. 5. Comparison of length-weight relationships of witch flounder of the Gulf of Maine, Mid-Atlantic Bight shelf and deep-water slope regions. End points of curves correspond to minimum and maximum lengths observed in each region.

TABLE 4. Summary of maturity observations for deep-water witch flounder by gender. Included in the total are 3 females and 10 males, which were mature but not classified into a maturity stage. One observation was omitted for a $26 \mathrm{~cm}$ female due to the poor condition of the gonad following freezing and thawing.

\begin{tabular}{lccccr}
\hline \hline Gender & Immature & Developing & Spent & Resting & Total \\
\hline Females & 111 & 1 & 0 & 56 & 171 \\
Males & 41 & 25 & 3 & 20 & 99 \\
\hline
\end{tabular}

New England were "stunted expatriates" of that population. First, the presence of witch flounder eggs south of New England during February-April (Berrien and Sibunka, 1999) would argue for localized spawning, and against passive transport via shelf water circulation of eggs and larvae from the laterspawning (May-June) Gulf of Maine population. In this study, the observation of 25 males and one female with developing gonads, and three males with spent testes (Table 4), suggests that these deep-water witch flounder are indeed reproductively active.

Secondly, the observed differences in otolith shape and microstructure between regions, combined with differences in length-weight relationships, would seem to suggest that deep-water witch flounder are 'growing' 
TABLE 5. Results of witch flounder maturity analyses, including sample sizes, estimates of median length $\left(L_{50}\right)$ and age $\left(A_{50}\right)$ at maturity and $95 \%$ confidence intervals, by region and gender.

\begin{tabular}{lrrrrr}
\hline \hline Region and gender & $\mathrm{N}$ & $L_{50}$ & $(95 \% \mathrm{CI})$ & $A_{50}$ & $(95 \% \mathrm{CI})$ \\
\hline Gulf of Maine & & & & & \\
$\quad$ Females & 855 & 34.2 & $(33.6-34.8)$ & 5.1 & $(4.9-5.2)$ \\
$\quad$ Males & 964 & 27.3 & $(26.8-27.8)$ & 3.5 & $(3.4-3.6)$ \\
& & & & & \\
Deep-water & & & & & \\
All depths & 171 & 36.4 & $(35.5-37.4)$ & & $(8.2-9.7)$ \\
$\quad$ Females & 99 & 30.2 & $29.3-31.2)$ & & \\
$\quad$ Males & & & & & \\
367-500 m & 103 & 36.3 & $(35.1-37.7)$ & & \\
$\quad$ Females & 69 & 30.3 & $(29.0-31.8)$ & & \\
$\quad$ Males & & & & & \\
>500 m & 68 & 36.6 & $(35.3-38.5)$ & & \\
$\quad$ Females & 30 & 30.0 & $(26.0-31.8)$ & & \\
$\quad$ Males & & & & & \\
\hline
\end{tabular}

differently, independent of growth rate. Scott (1954) found differences in otolith appearance and head length for another flatfish species, yellowtail flounder (Limanda ferruginea), in Canadian waters and off Cape Cod. Otolith shape would most likely be an artifact of neurocranial anatomy, particularly the supraoccipital bone (Bond, 1979). The relatively high exponent in the length-weight equation results in fish, which are stubbier in appearance, hence Markle's (1975) description of "stunted". No attempt was made in this study to collect meristic or morphometric data, but traditional stock identification studies or those using newer methodologies involving DNA or elemental composition of otoliths, would be logical topics for future research.

Finally, pronounced differences in biological (growth and maturation) and production (yield and spawning stock biomass per recruit) characteristics between deep-water witch flounder and the Gulf of Maine populations would seem to define them as separate groups. The deep-water population would have to be carefully managed to avoid growth overfishing given its yield characteristics. Gear selectivity would be a critical component in any potential fishery on this group, since discard mortality would be virtually total for the depths at which this fishery would be prosecuted, even for a species lacking a swim bladder.
Individually, these arguments may appear problematic, but collectively, and combined with the lack of any known migratory mechanism for this species, our observations support the likelihood that these deep-water witch flounder are in fact a separate population from the Gulf of Maine - Georges Bank group. Our preliminary findings provide the basis for on-going research into witch flounder stock dynamics off the U.S. coast.

A more interesting question, although unanswered by this study, is the linkage between deep-water witch flounder and those occurring in continental shelf waters from southern New England southwards. Given the distribution patterns of eggs (Berrien and Sibunka, 1999) and larvae (Smith et al., 1975), it is possible that these two groups are closely associated. The deepwater fish may represent a component of the shelf population that has moved down the slope, analogous to the observation of Kuzmin (MS 1989) that witch flounder of the Grand Banks population (NAFO Div. $3 \mathrm{LNO}$ ) were often distributed at depths greater than $366 \mathrm{~m}$ in Newfoundland slope waters. Such movement could alter growth and maturation characteristics due to environmental influences; the constant temperature and darkness associated with greater depths might also eliminate the seasonal stimuli fish require for reproduction (Bye, 1984). There are examples in the literature in which such changes in habitat have 

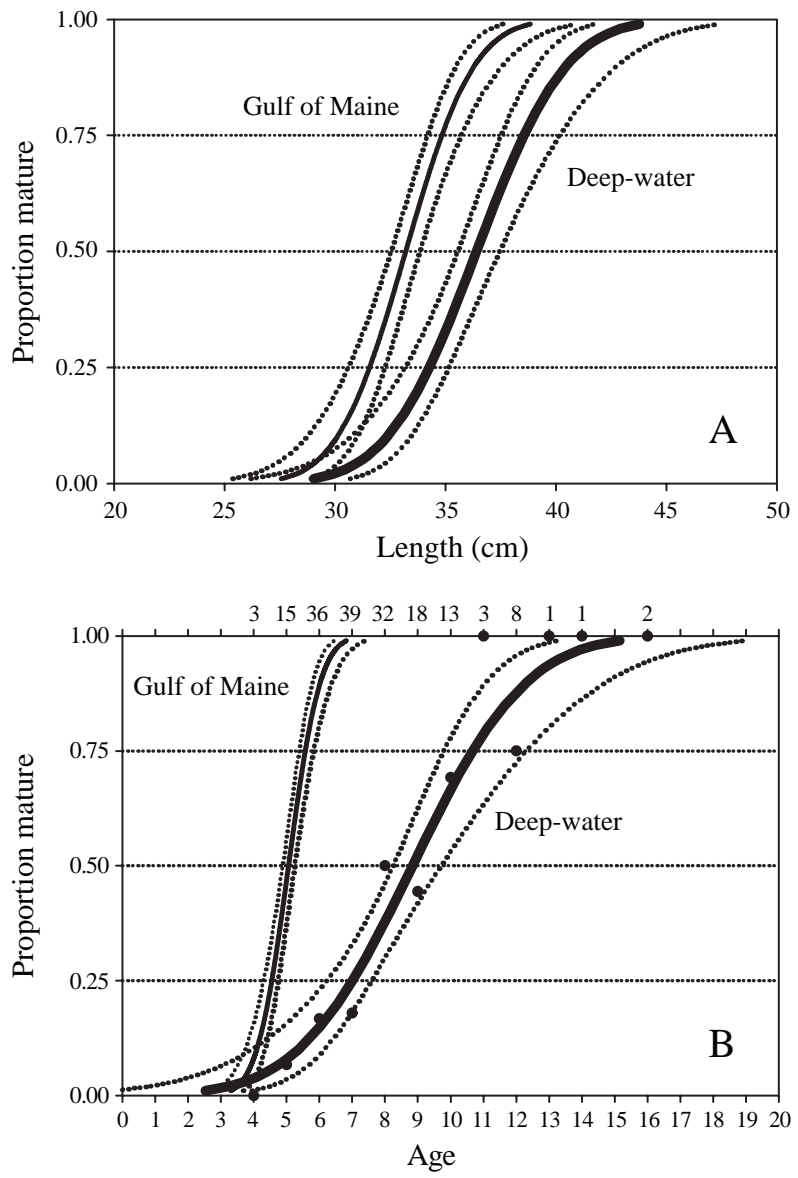

Fig. 6. Maturity curves and associated 95\% confidence intervals for female witch flounder from the Gulf of Maine and deep-water regions; estimated proportions mature-at-length (A) and mature-at-age (B) are shown. Data points in B represent observed proportions mature; sample sizes are shown along the top axis.

resulted in cessation of reproduction and the continuation of juvenile growth, creating large, asexual individuals (lanternfish, Myctophum punctatum in the Northwest Atlantic (Zurbrigg and Scott, 1972) and redfish, Sebastes sp. off Newfoundland (Sandeman, 1969)). In this study, the observation of a lower growth rate as well as the presence of mature fish would seem to contradict this scenario, but nothing is known about the reproductive cycle of these deep-water witch flounder, and it is possible that spawning has become non-annual, aperiodic, and asynchronous. Indeed, the additional energy available for somatic growth in the absence of reproduction might well explain the length-weight relationship for this group of fish. In the end, Markle's (1975) "stunted expatriates" might be exactly that, only originating

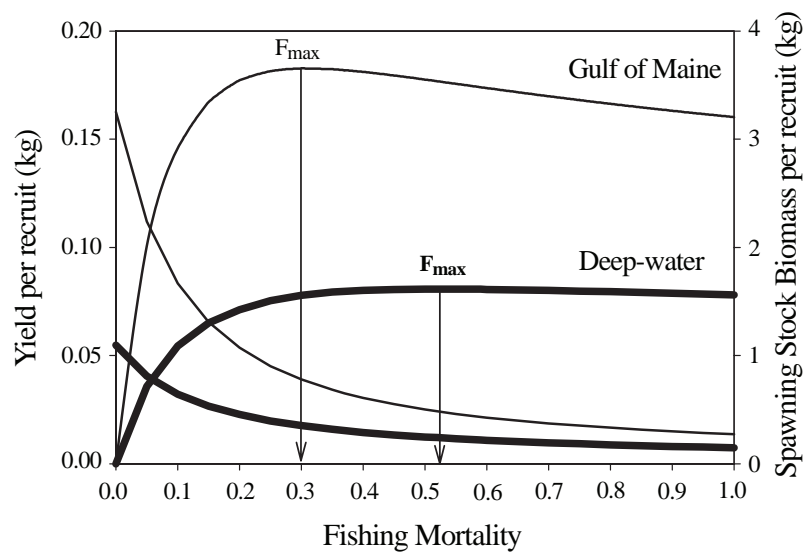

Fig. 7. Comparisons of yield and spawning stock biomass per recruit estimates for Gulf of Maine and deepwater witch flounder obtained using the method of Thompson and Bell (1934). The levels of fishing mortality at which maximum yields occurs $\left(F_{\max }\right)$ are shown. Input values for these analyses are provided in Appendix Table 2.

from a southern New England - Mid-Atlantic continental shelf population that is sustained by its own reproductive efforts and an unknown but certainly diminished contribution from the deep-water component.

An alternative hypothesis may be that the deepwater population owes its existence instead to fish far to the north. Witch flounder are characterized by a lengthy pelagic larval stage, from as much as six months to a year (Evseenko and Nevinsky, MS 1973). Larvae from spawning events off Labrador, Newfoundland, and the Grand Banks during spring and summer (see Bowering, 1990) may be passively transported via slope water circulation associated with the Labrador Current (Rossby and Benway, 2000; Drinkwater et al., in review). Drinkwater et al. (in review) described the movement of cold Labrador Slope Water from the Grand Banks region in summer 1997 to the Mid-Atlantic Bight region by March 1998, a scenario spatially and temporally plausible for witch flounder larval transport. However, much additional research, particularly in the form of increased sampling of the deep-water component, is required before either hypothesis can be adequately evaluated.

\section{Acknowledgements}

We thank all participants of the deep-water cruises aboard the F/V Contender, F/V Warrior, F/V Mary K. and $F / V$ Drake as well as NEFSC staff and volunteers 
aboard the NEFSC bottom trawl surveys who collected the deep-water specimens for this study. We thank all reviewers for their helpful comments.

\section{References}

AZAROVITZ, T. R. 1981. A brief historical review of the Woods Hole Laboratory trawl survey time series. In: Bottom trawl surveys. W.G. Doubleday and D. Rivard (eds.). Can. Spec. Publ. Fish. Aquat. Sci., 58: 62-67.

BERRIEN, P. and J. SIBUNKA. 1999. Distribution patterns of fish eggs in the U.S. Northeast Continental Shelf Ecosystem, 1977-1987. NOAA Tech. Rep., NMFS 145, $310 \mathrm{p}$.

BIGELOW, H. B. and W. C. SCHROEDER. 1953. Fishes of the Gulf of Maine. U.S. Fish Wildl. Serv., Fish. Bull., 74: $577 \mathrm{p}$.

BOND, C. E. 1979. Biology of fishes. W. B. Saunders Co., Philadelphia, PA, $514 \mathrm{p}$.

BOWERING, W. R. 1990. Spawning of witch flounder (Glyptocephalus cynoglossus, L.) in NewfoundlandLabrador area of the northwest Atlantic as a function of depth and water temperature. Fish. Res., 9: 23-39.

BOWERING, W. R. and D. E. STANSBURY. 1984. Regressions of weight on length for witch flounder, Glyptocephalus cynoglossus, of the eastern Newfoundland area. J. Northw. Atl. Fish. Sci., 5: 105106.

BOWERS, A. B. 1960. Growth of the witch (Glyptocephalus cynoglossus) in the Irish Sea. ICES J. Cons., 25: 168176.

BOWMAN, R. E. and W. L. MICHAELS. 1984. Food of seventeen species of northwest Atlantic fish. NOAA Tech. Mem., NMFS-F-NEC-28, 183 p.

BURNETT, III, J. M. MS 1987. The population biology of the witch flounder, Glyptocephalus cynoglossus (L.), in the Gulf of Maine-Georges Bank region. Master of Science Thesis, Dept. of Wildlife and Fisheries Biology, University of Massachusetts, Amherst, MA, 116 p.

BURNETT, J. 1988. Witch flounder. In: Age determination methods for Northwest Atlantic species. J. Penttila and L. M. Dery (eds.). NOAA Tech. Rep., NMFS 72, p. 109110.

BURNETT, J., L. O'BRIEN, R. K. MAYO, J. DARDE, and M. BOHAN. 1989. Finfish maturity sampling and classification schemes used during the Northeast Fisheries Center bottom trawl surveys, 1963-89. NOAA Tech. Mem., NMFS-F/NEC-76, $14 \mathrm{p}$.

BURNETT, J., M. R. ROSS, and S. H. CLARK. 1992. Several biological aspects of the witch flounder (Glyptocephalus cynoglossus (L.)) in the Gulf of Maine-Georges Bank region. J. Northw. Atl. Fish. Sci., 12: 15-25.

BYE, V. J. 1984. The role of environmental factors in the timing of reproductive cycles. In: Fish Reproduction: Strategies and Tactics. Potts, G. W. and R. J. Wootton (eds). Academic Press, London, UK, p.187-205.

DRINKWATER, K. F., D. B. MOUNTAIN, and A. HERMAN. In review. Variability in the slope water properties off
Eastern North America and their effects on the adjacent shelves. J. Geophys. Res.

EVSEENKO, S. A., and N. M. NEVINSKY. MS 1973. Breeding and development of witch flounder (Glyptocephalus cynoglossus) in the Northwest Atlantic Ocean. ICNAF Res. Doc., No. 49, Ser. No. 2990, 23 p.

FINNEY, D. J. 1971. Probit analysis. $3^{\text {rd }}$ ed. Cambridge University Press, $333 \mathrm{p}$.

GOODE, G. B., and T. H. BEAN. 1895. Oceanic ichthyology. Smithsonian Contrib. Knowl., Vol. 30(xxv), 533 p.

KLEIN-MACPHEE, G. 2002. Righteye flounders. Family Pleuronectidae. In: Bigelow and Schroeder's fishes of the Gulf of Maine. B. B. Collette and G. Klein-MacPhee (eds.), Smithsonian Institution Press, p.560-587.

KOHLER, A. C., D. N. FITZGERALD, R. G. HALLIDAY, J. S. SCOTT, and A. V. TYLER. MS 1970. Length-weight relationships of marine fishes of the Canadian Atlantic region. Fish. Res. Board Can. Tech. Rep., No. 164, 11 p.

KUZMIN, S. MS 1989. Estimation of witch stock in Div. $3 \mathrm{LNO}$ according to the data on 1983-88 trawl surveys. NAFO SCR Doc., No. 7, Serial No. N1571, 9 p.

LUX, F. E. 1969. Length-weight relationships of six New England flatfishes. Trans. Am. Fish. Soc., 98(4): 617621.

MARKLE, D. F. 1975. Young witch flounder, Glyptocephalus cynoglossus, on the slope off Virginia. J. Fish. Res. Board Can., 32: 1447-1450.

MARKLE, D. F. and J. A. MUSICK. 1974. Benthic slope fishes found at $900 \mathrm{~m}$ depth along a transect in the western N. Atlantic Ocean. Mar. Biol., 26: 225-233.

MORGAN, M. J. and J. M. HOENIG. 1997. Estimating maturity-at-age from length stratified sampling. J. Northw. Atl. Fish. Sci., 21: 51-63.

NILSEN, R., O. K. GUTVIK, E. M. NILSSEN, and C. C. E. HOPKINS. 1991. Population parameters of the witch flounder Glyptocephalus cynoglossus (L.) (Pisces: Pleuronectidae) from Malangen, northern Norway. Fish. Res., 12: 259-278.

O'BRIEN, L., J. BURNETT, and R. K. MAYO. 1993. Maturation of nineteen species of finfish off the northeast coast of the United States, 1985-1990. NOAA Tech. Rep., NMFS 113, $66 \mathrm{p}$.

PENTTILA, J., F. NICHY, J. W. ROPES, L. M. DERY, and A. JEARLD, Jr. 1988. Methods and Equipment In: Age determination methods for Northwest Atlantic species. NOAA Tech. Rep., NMFS 72, p. 7-16.

POWLES, P. M. 1967. Length-weight relationships for American plaice, witch, and yellowtail, in ICNAF Subarea 4. ICNAF Res. Bull., 4: 121-123.

ROFF, D. A. 1980. A motion for the retirement of the von Bertalanffy equation. Can. J. Fish. Aquat. Sci., 37: 127129.

ROSSBY, T. and R. L. BENWAY. 2000. Slow variations in mean path of the Gulf Stream east of Cape Hatteras. Geophys. Res. Letters, 27: 117-120.

SAS Institute, Inc. 1985. SAS User's Guide: Statistics. Version 5. SAS Institute, Cary, North Carolina. 956 p.

SANDEMAN, E. J. 1969. Age determination and growth rate of redfish, Sebastes sp., from selected areas around 
Newfoundland. ICNAF Res. Bull., 6: 79-106.

SCOTT, D. M. 1954. A comparative study of the yellowtail flounder from three Atlantic fishing areas. J. Fish. Res. Board. Can., 11: 171-197.

SMITH, W. G., J. D. SIBUNKA, and A. WELLS. 1975. Seasonal distributions of larval flatfish (Pleuronectiformes) on the continental shelf between Cape Cod and Cape Lookout, N.C., 1965-66. NOAA Tech. Rep. Spec. Sci. Rep. Fish., 691: 68 p.

SOKAL, R. R. and F. J. ROHLF. 1995. Biometry. $3^{\text {rd }}$ ed. W.H. Freeman and Company, New York, 887 p.

STEINARSSON, B. A. E., G. JONSSON, and H. GUDFINNSSON. MS 1989. Preliminary report on recent investigations on the biology and catch and effort data of witch (Glyptocephalus cynoglossus) in Icelandic waters. ICES C.M. Doc., G:63, 15 p.

THOMPSON, W. F. and F. W. BELL. 1934. Biological statistics of the Pacific halibut fishery. 2. Effect of changes in intensity upon total yield and yield per unit of gear. Rep. Int. Pac. Halibut Comm., 8: 1-49.

WIGLEY, S. E. MS 1994. Estimation of foregone yield associated with the discarding of witch flounder (Glyptocephalus cynoglossus) in the Gulf of Maine northern shrimp (Pandalus borealis) fishery, 1982-1992. Master of Science Thesis, Dept. of Biomathematics, North Carolina State University, Raleigh, NC, 91 p.

WIGLEY, S. E., J. K. T. BRODZIAK, and S. X. CADRIN. MS 1999. Assessment of the witch flounder stock in Subareas 5 and 6 for 1999. NEFSC Ref. Doc., No. 99$16,153 \mathrm{p}$.

ZURBRIGG, R. E. and W. E. SCOTT. 1972. Evidence for expatriate populations of the lanternfish Myctophum punctatum in the northwest Atlantic. J. Fish. Res. Board Can., 29: 1679-1683. 
APPENDIX TABLE 1. Numbers and total lengths of witch flounder, Glyptocephalus cynoglossus, caught during the NEFSC red crab survey AL 80-05, July 1980, in the southern New England region.

\begin{tabular}{|c|c|c|c|c|c|}
\hline Station & Depth range $(\mathrm{m})$ & Latitude & Longitude & Numbers & Lengths $(\mathrm{cm})$ \\
\hline 1 & $273-298$ & 3959 & 7036 & 0 & \\
\hline 2 & $1571-1627$ & 3947 & 7045 & 0 & \\
\hline 3 & $1600-1719$ & 3947 & 7047 & 0 & \\
\hline 4 & $668-677$ & 3953 & 7056 & 4 & $8,17,25,25$ \\
\hline 5 & $936-971$ & 3950 & 7059 & 3 & $7,23,26$ \\
\hline 6 & $1117-1130$ & 3946 & 7121 & 1 & 18 \\
\hline 7 & $513-530$ & 3955 & 7103 & 7 & $6,9,9,9,21,26,34$ \\
\hline 8 & $337-338$ & 3959 & 7055 & 8 & $19,26,28,29,29,31,32,35$ \\
\hline 9 & $711-744$ & 3952 & 7038 & 0 & \\
\hline 10 & $432-443$ & 3955 & 7036 & 0 & \\
\hline 11 & $549-625$ & 3954 & 7032 & 1 & 10 \\
\hline 12 & $969-1234$ & 3951 & 7030 & 0 & \\
\hline 13 & $326-331$ & 3959 & 7020 & 1 & 26 \\
\hline 14 & $358-358$ & 3955 & 6949 & $*$ & \\
\hline 15 & $428-433$ & 3953 & 6947 & 3 & $19,25,26$ \\
\hline 16 & $777-823$ & 3951 & 6950 & 5 & $8,8,21,24,24$ \\
\hline 17 & $348-366$ & 3954 & 6943 & 3 & $7,16,29$ \\
\hline 18 & $404-561$ & 3954 & 6932 & 0 & \\
\hline 19 & $883-1170$ & 3952 & 6932 & 3 & $22,23,30$ \\
\hline 20 & $1015-1052$ & 3951 & 6921 & 0 & \\
\hline 21 & $713-841$ & 4003 & 6902 & 0 & \\
\hline 22 & $366-421$ & 4003 & 6901 & $*$ & \\
\hline 23 & $366-649$ & 4003 & 6901 & 0 & \\
\hline 24 & $218-221$ & 4003 & 6858 & 0 & \\
\hline 25 & $1116-1371$ & 3958 & 6855 & 2 & 26,29 \\
\hline
\end{tabular}

* incomplete tow due to gear problems. 
APPENDIX TABLE 2. Input parameters and results from Thompson-Bell yield-per-recruit modeling for Gulf of Maine and deep-water witch flounder.

Gulf of Maine witch flounder

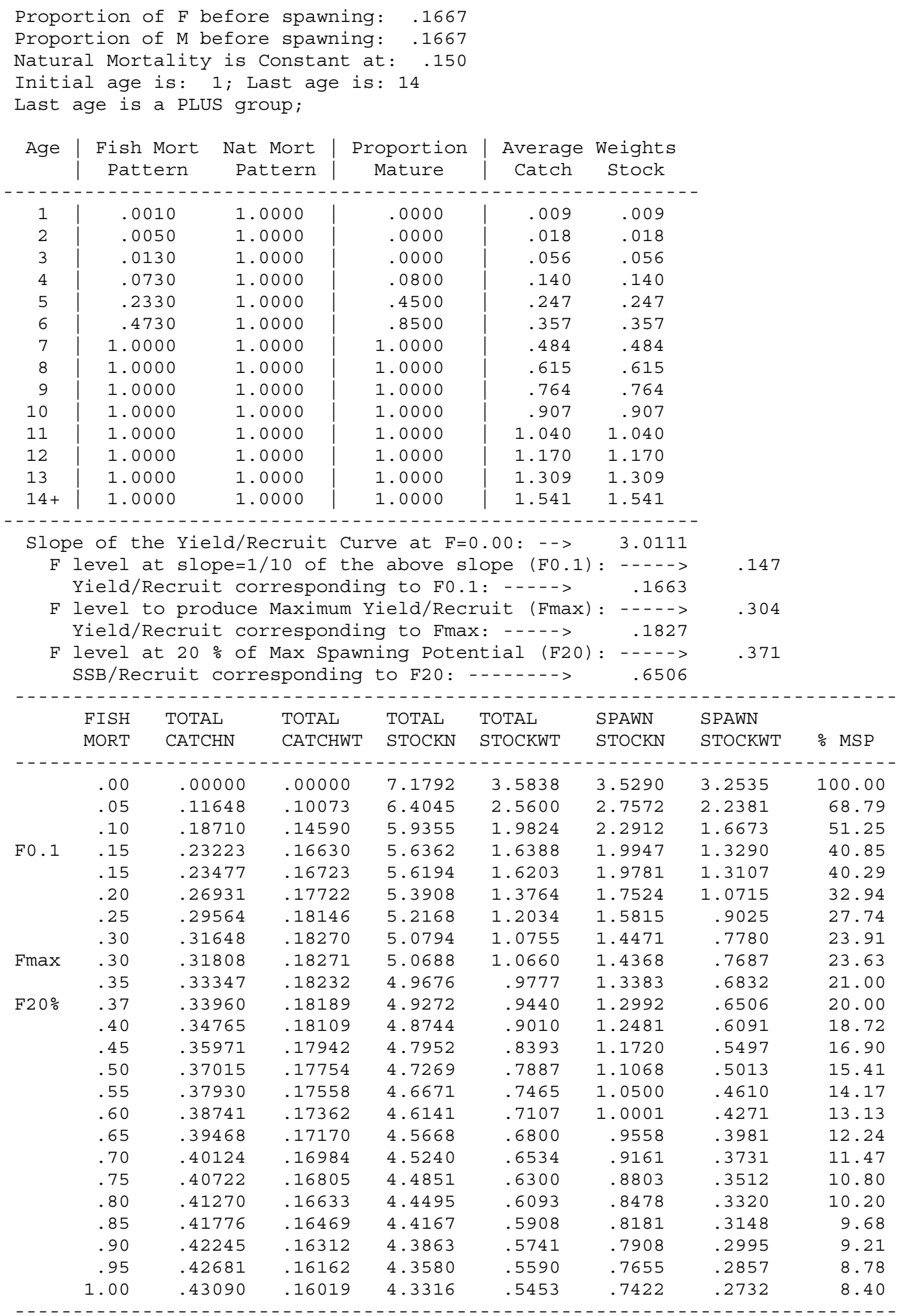


APPENDIX TABLE 2. Continued.

$\underline{\text { Deep-water witch flounder }}$

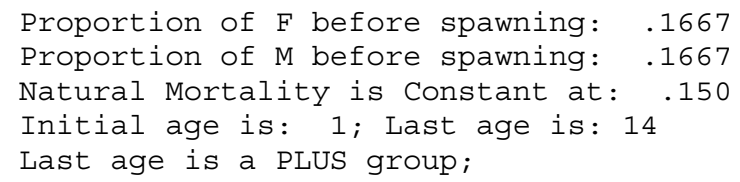

\begin{tabular}{c|cc|c|c} 
Age & $\begin{array}{c}\text { Fish Mort } \\
\text { Pattern }\end{array}$ & $\begin{array}{c}\text { Nat Mort } \\
\text { Pattern }\end{array}$ & $\begin{array}{c}\text { Proportion } \\
\text { Mature }\end{array}$ & $\begin{array}{c}\text { Average Weights } \\
\text { Catch }\end{array}$ \\
Stock
\end{tabular}

Slope of the Yield/Recruit Curve at $F=0.00:->\quad 1.0020$

F level at slope=1/10 of the above slope (F0.1): -.-.-> Yield/Recruit corresponding to F0.1: -..-> . .0712

F level to produce Maximum Yield/Recruit (Fmax) : --.--> Yield/Recruit corresponding to Fmax: ----> .0807

F level at $20 \%$ of Max Spawning Potential (F20): ----> SSB/Recruit corresponding to F20:------> .2189

\begin{tabular}{|c|c|c|c|c|c|c|c|c|}
\hline & FISH & TOTAL & TOTAL & TOTAL & TOTAL & SPAWN & SPAWN & \\
\hline & MORT & CATCHN & CATCHWT & STOCKN & STOCKWT & STOCKN & STOCKWT & $\%$ MSP \\
\hline & $-\ldots \ldots$ & $\ldots$ & $-\ldots-\ldots-\ldots$ & $\ldots$ & $-\ldots$ & $\ldots$ & -------- & $-\ldots-\ldots$ \\
\hline & .00 & .00000 & .00000 & 7.1792 & 1.4392 & 2.1568 & 1.0945 & 100.00 \\
\hline & .05 & .06572 & .03566 & 6.7420 & 1.1404 & 1.7447 & .8100 & 74.00 \\
\hline & .10 & .10634 & .05440 & 6.4723 & .9618 & 1.4944 & .6417 & 58.63 \\
\hline & .15 & .13434 & .06510 & 6.2865 & .8431 & 1.3252 & .5312 & 48.53 \\
\hline F0.1 & .20 & .15414 & .07124 & 6.1552 & .7623 & 1.2079 & .4569 & 41.75 \\
\hline & .20 & .15509 & .07150 & 6.1489 & .7585 & 1.2023 & .4535 & 41.43 \\
\hline & .25 & .17128 & .07542 & 6.0418 & .6951 & 1.1085 & .3960 & 36.18 \\
\hline & .30 & .18439 & .07782 & 5.9551 & .6457 & 1.0342 & .3520 & 32.16 \\
\hline & .35 & .19533 & .07927 & 5.8829 & .6061 & .9735 & .3172 & 28.98 \\
\hline & .40 & .20466 & .08011 & 5.8213 & .5735 & .9229 & .2891 & 26.41 \\
\hline & .45 & .21277 & .08055 & 5.7678 & .5463 & .8798 & .2659 & 24.29 \\
\hline & .50 & .21993 & .08071 & 5.7206 & .5231 & .8425 & .2465 & 22.52 \\
\hline Fmax & .52 & .22224 & .08072 & 5.7054 & .5157 & .8307 & .2404 & 21.97 \\
\hline & .55 & .22633 & .08069 & 5.6785 & .5030 & .8099 & .2300 & 21.01 \\
\hline$F 20 \%$ & .59 & .23081 & .08060 & 5.6490 & .4893 & .7875 & .2189 & 20.00 \\
\hline & .60 & .23210 & .08056 & 5.6405 & .4855 & .7811 & .2158 & 19.71 \\
\hline & .65 & .23736 & .08034 & 5.6059 & .4700 & .7553 & .2034 & 18.59 \\
\hline & .70 & .24219 & .08007 & 5.5742 & .4561 & .7320 & .1926 & 17.60 \\
\hline & .75 & .24665 & .07976 & 5.5449 & .4437 & .7109 & .1830 & 16.72 \\
\hline & .80 & .25079 & .07944 & 5.5177 & .4324 & .6916 & .1744 & 15.93 \\
\hline & .85 & .25465 & .07910 & 5.4923 & .4221 & .6740 & .1667 & 15.23 \\
\hline & .90 & .25827 & .07875 & 5.4685 & .4127 & .6576 & .1598 & 14.60 \\
\hline & .95 & .26168 & .07841 & 5.4461 & .4040 & .6425 & .1534 & 14.02 \\
\hline & 1.00 & .26490 & .07807 & 5.4250 & .3960 & .6284 & .1477 & 13.49 \\
\hline
\end{tabular}

